\title{
The Quality of Leaders is Truly Engaging for an Organizational Core
}

\author{
Rudrarup Gupta* \\ Commercial Manager, Multifarious Projects Group, India
}

Submission: May 03, 2018; Published: May 08, 2018

"Corresponding author: Dr. Rudrarup Gupta Instaed of Rudrarup Gupta, Commercial Manager, Multifarious Projects Group, Kolkata, India, Email: rudrarupgupta21@gmail.com

Abstract

It is needless to convey that leaders do have the bottomless entity in an organization right from the beginning. On the other hand this great occupational splendour truly reflects upon the high-end occupational celerity of those desirous employees, who are the best core of an organizational elegance. In other words followers are the introspective resource not only to remake the real organizational image but to restyle the present day organizational paradigm in deed. That is the reason why both leaders and the followers do establish their professional management as per the destined need and the conceptual veracity respectively. As a matter of the fact is both leaders and managers are in a same delicate platform to regulate their organization through conception, perception, ambition, aspiration and acceleration at all.

Keywords: Qualitative base; Leader's competency; Occupational Passion; Perceptual rise

\section{Introduction}

Leaders do focus upon their self competency and the spirited organizational goal. That is why they are in a prior position to build an astounding team with robust training. Not only that leaders and their followers do elevate their mind frame with all the possible resources. But they should follow the certain attributes:

Self esteem: It is an astounding key to refine all the followers as a hole. Because it is really conducive for self assessment. On the other hand both leaders and followers should have the same to drive them towards the hazardless destiny.

Self zeal: It enhances the capacity of the followers. As a result all the employees get motivated and they do provide the best from their end for the utmost organizational magnificence.

Self recognition: It is indeed very essential for both leaders and followers to be properly recognised in deed. On the other hand this occupational recognition may ensure the highest spirit of hard work alongside the remarkable tenacity for an organization.

Self evaluation: Leaders do create such wonderful occupational ambience, where each follower can have the real opportunity to evaluate their best potentials. Moreover it is exclusively worthwhile to assess their present status and conducive to participate with their sound professional core from day one.

\section{Reference [1]}

As per Asrar-ur-Haq Muhammad and Kuchinke K. Peter and their article entitled: Impact of Leadership Styles on Employees' attitude towards their leader and performance: Empirical evidence from Pakistani banks it says that this paper is to examine the impact of managers.

In other words leaders should have the following attributes in deed:

Understanding: All the enriched leaders should have the great understanding for each and other. In the same light this real quality shall be truly effective for the amicable progress of an organization.

Foresight: Leaders shall have to understand that what is going to be happened. They shall have to proceed accordingly. On the other hand they shall be able to evaluate their present situation through the process of both organizational output and the self assessment. Therefore it shall be truly beneficial for them not only to run the organization but to estimate the forthcoming occupational perspectives accordingly.

Politeness: It is such a magnificent quality, which can be truly compelling for the leaders to implement and it shall be really appropriate for the followers to receive to build an astounding professional bonding and to put the best effort for the organization.

Educational Richness: It is having an absolute essentiality for both leaders and followers to enhance their highest educational depth, which is really effective for them to defend the situation and to recover the unavoidable resilience respectively.

Broadness: It is purely important for a leader to be absolutely broad for their employees and for all the clients, whom they shall 
be getting in touch with for long. This is how an indispensible connection will be taking place and it shall be favourable for the rapid organizational growth in deed.

\section{Reference [2]}

As per Solomon Anthony and Steyn Renier and their article entitled: Leadership Style and Leadership Effectiveness: Does cultural intelligence moderate the relationship? It says that subordinate cultural heterogeneity has become the norm. On the other hand leaders can have the support from cultural intelligence to enhance the effectiveness.

\section{Conclusion}

It is quite evident that leaders are the rejuvenated sheet anchors for the remarkable progression at all. On the other hand they are the most painstaking guides and mentors sometimes for their highly ambitious followers to provide them the everlasting illumination of incalculable achievements with their aspired occupational brilliance forthcoming hopes to stay alive.

\section{References}

1. Asrar-ur-Haq Muhammad, Kuchinke KP (2016) Impact of Leadership Styles on Employees' attitude towards their leader and performance: Empirical evidence from Pakistani banks. Future Business Journal 2(1): 54-64.

2. Anthony S, Renier S (2017) Leadership Style and Leadership Effectiveness: Does cultural intelligence moderate the relationship? Independent Research Journal in The Management Sciences 17(1).

\begin{tabular}{l} 
Your next submission with Juniper Publishers \\
will reach you the below assets \\
- Quality Editorial service \\
- Swift Peer Review \\
- Reprints availability \\
- E-prints Service \\
- Manuscript Podcast for convenient understanding \\
- Global attainment for your research \\
- Manuscript accessibility in different formats \\
( Pdf, E-pub, Full Text, Audio) \\
- Unceasing customer service \\
Track the below URL for one-step submission \\
https://juniperpublishers.com/online-submission.php \\
\hline
\end{tabular}

